\title{
Impact of Capital Market on Economic Growth in Nigeria
}

\author{
Ubesie M. C. ${ }^{1}$, Nwanekpe C. E. ${ }^{2} \&$ Ejilibe C. ${ }^{1}$ \\ ${ }^{1}$ Accountancy Department ESUT, Nigeria \\ ${ }^{2}$ Finance and Account Department National Bureau of Statistics Abuja, Nigeria \\ Correspondence: Ubesie M. C., Accountancy Department ESUT, Nigeria. E-mail: ubesiemadubuko@yahoo.com
}

Received: June 17, 2020

doi:10.5430/bmr.v9n2p49

\author{
Accepted: July 3, 2020 \\ Online Published: July 3, 2020 \\ URL: https://doi.org/10.5430/bmr.v9n2p49
}

\begin{abstract}
This study on "Impact of Capital Market on Economic Growth in Nigeria" is aimed to access the impact and determinant of capital market on the economic growth in Nigeria within the period of study. It further employed the ordinary least square method (OLS) in analyzing the time series variables obtained for the study. The result of the findings show that all the variables of interest were significant in explaining the behavior of capital market on the growth of Nigeria Economy except Labour force. more so, the result show that the the model employed for the analysis is adequate and best in fitting the variables obtained. Further more, necessary recommendations were made to enable the government come up with a favorable policies in which will make for improvement in the standard of living.
\end{abstract}

Keywords: Capital market, Economy, ECM, Stationarity and Co integration

\section{Introduction}

The capital market is essentially a market for long term securities such as stock, debentures and bonds lasting for usually longer than three years. It is the cornerstone of every financial system which provides the funds needed for financing not only business and other economic institutions, but also the programme of government as a whole. According to Ewah Sunday, Atim Esang and Bassey Jude (2009), capital market provides the opportunity for the purchase and sale of existing securities among investors thereby encouraging the populace to invest in securities fostering economic growth. It offers access to variety of financial instruments that enables economic agents to pool, price and exchange.

The capital market institution is critical to the economic growth of any nation. It is a network of specialized financial institutions, series of mechanisms, process and infrastructure that, in various ways, facilitate the bringing together of suppliers and users of medium to long-term capital for investment in socio-economic developmental projects (Al-Faki, 2006). It is a market for dealing (that is lending and borrowing) in long term loanable funds (Ekezie, 2002). The capital market is subdivided into the primary and secondary market. The primary market or the new issues market provides the avenue through which government and cooperate bodies raise fresh funds through the issuance of securities which is subscribed to by the public or a selected group of investors. The secondary market provides an avenue for sale and purchase of existing securities. Sule and Momoh (2009) found that the secondary market activities have impacted more on Nigeria per capital income by tending to grow stock market earnings through wealth than the primary market.

In the light of the above background, the question that would come to mind is whether or not capital market has impacted the economy of Nigeria significantly, given the enabling environment provided by the supportive democratic system. The strength of an economy is partly dependent on how competently the capital market is performing its allocative function of capital. Thus, it is very important to assess the effect of capital market on economic growth in Nigeria. However, in a bid to ascertain the effect of capital market on economic growth in Nigeria, the study must strive to examine the effect of stock market capitalization, savings accumulation, labour force, and gross fixed capital formation on real gross domestic product in Nigeria.

\section{Conceptual Review}

Essentially, the Capital Market plays a lot of roles in the development of the economy which may include but not limited to:

i. providing opportunities for companies to borrow funds needed for long term investment purposes. 
ii. providing an avenue for the marketing of shares and other securities in other to raise fresh funds for expansion of operations leading to increase in output/ production.

iii. providing a means of allocating the nations real and financial resources between, various industries and companies. Through the capital formation and allocation mechanism the capital market ensures an efficient and effective distribution of scarce resources for the optimal benefit of the economy.

iv. reducing the overall reliance of the corporate sector on short term financing for long term projects and also provides opportunities for government to finance project aimed at providing essential amenities for socio-economic development.

v. aiding the government in its privatization programme by offering her shares in the public enterprises to members of the public through the stock exchange and many more.

\subsection{The Nigerian Financial System}

In Nigeria, the financial system is made up of two major markets namely: the money market and the capital market. The money market is the short-term funds and securities, including treasury bills, one- year treasury certificates, Central Bank notes, negotiable certificates of deposit, commercial papers, commercial and merchant bank savings and investment notes and other funds of less than one-year duration. On the other hand, the Capital Market is for longer term funds and securities whose tenure extend beyond one year. These include long- term loans, mortgage bonds, preference stocks, ordinary shares, federal Government bonds, industrial loans and debentures. According to Osaze (2007), capital market is a complex institution and mechanism through which intermediate funds and long-term funds are pooled and made available to business, government and individuals and instrument already outstanding are transferred. The institutions that interact within the capital market are: Insurance companies, pension found Administrators, Central Bank of Nigeria, Nigerian Stock Exchanges, Professional bodies, Corporate Affairs commission, Financial Reporting council, Ministry of Finance, Investment and securities Tribunal, market intermediaries, Investors, media, etc. these institutions which traditionally play one role or the other in the transfer of funds from saving public to users include stock exchanges, stock registrars, issuing houses, stockbrokers, underwriters and security and exchange commission.

Impact of Commercial Banks: Following the full capitalization of banks to a minimum of N25billion, almost all banks utilized and accessed the capital market to raise funds. Within two years, plus, many of the banks besieged the capital market more than once, falling over one another in raising funds through mega offers in a single tranche. The banks competed to suck every liquidity from the Nigerian financial system, thus overheating it. Through enticing marketing strategies, the banks succeeded in their various offers, but left the capital market place bleeding and gasping for breath. The primary market seemed to experience a boom while the secondary market was sucked dry as many investors dumped their shares in the secondary market was sucked dry as many investors achieved through bewitching marketing efforts of banks and many others.

\subsection{Economic Growth}

Economic growth means an increase in the capacity of an economy to produce goods and services, compared from one period of time to another. Economic growth is a process by which a nation wealth increases over time. The most widely used measures of economic growth is the rate of growth in a country's total output of goods and services gauged by the gross domestic product (GDP) Economic growth can also be refers to as the increase of per capita gross domestic product (GDP) or other measures of aggregate income, typically reported as the annual rate of change in the real GDP. Economic growth is primarily driven by improvement in productivity, which involves producing more goods and services with the same inputs of labour, capital, energy and materials. (Wikipedia).

\section{Review}

\subsection{Information Asymmetry}

The work examined traded commodities quality in markets. Results of the work indicated that the traded goods quality reduce in the presence of informational differences between the buyer and the seller, thus, creating lemon probems. In America, this relates to newly bought cars which are faulty. It exists when a buyer is unable to distinguish a higher quality car and a lemon. In such a case, the customer pays for a car they perceive to be of high quality when in reality it is not. It is only the seller who knows whether the car is a lemon; (faulty) or not (high quality). This presents a problem of adverse selection which arises when buyers make decision on incomplete or incorrect information. 


\subsection{Empirical Literature}

Dowa and Odia (2010) empirically analyzed the impact of Nigerian capital market on her socio- economic development. The study used a sample period of 1981-2008. The methodology adopted was ordinary least square regression and the result showed that the capital market indices did not have significant impact on the GDP in Nigeria

Kolapo and Adaramola (2012) examined the impact of the Nigerian capital market on economic growth from 1990-2010. They employed ordinary least squares (OLS) regression analysis procedures capturing to integration and granger causality. Their results revealed that activities in the capital market impact positively on the economy.

Oluwatosin, Adekanye \& Yusuf (2013) examined the impact of Nigerian capital market on economic growth and development between 1999 and 2012. The study explored secondary data collected from security Exchange Commission reports, Nigerian Stock Exchange Review Reports, and central Bank of Nigeria Statistical bulletin. Methodology employed was ordinary least square regression analysis while the result showed that capital market indices had not significantly impacted on the GDP in Nigeria. This was attributed to low market capitalization, low absorptive capitalization, illiquidity, and misappropriation of funds among others. The study therefore recommended that government should restore confidence to the market through regulatory authorities which would portray transparency, fair trading transactions and dealing in the stock exchange, improve dealing in the market capitalization by encouraging more foreign investors to participate in the market and also to increase investments instruments such as derivatives, convertibles, swap and option in the market.

Briggs (2015) empirically examined the impact of the capital market on the Nigeria economy from 1981-2011. The study used Gross Domestic product (GDP) as proxy for economic growth while the capital market variables considered were; Market capitalization (MCAP), total new issues (TNI), value of transactions (VLT), and total Listed Equities and government stocks (LEGS). Johansen co-integration and Granger causality tests were applied. The result showed the clear relative positive impact the capital market plays on the economic growth and invariably on the economy.

Kimeli (2017) studied IFRS adoption and capital markets. Through a review of relevant literature. The study which centred on IFRS adoption effects on the functioning and operations of capital markets, opined that enhanced liquidity of markets and minimized information asymmetry improved foreign holdings and turnover of capital markets.

Onulaka (2014) empirically investigated the effect of audit expectation gap in Nigeria capital. In the study, a cross sectional survey was conducted in Lagos and Abuja stock Exchange to capture the perception of key users of financial statements in Nigerian capital market. The study employed the Chi-square (x2) test techniques and discovered a wide expectation gap in the areas of auditors ' responsibility for fraud prevention and detection in Nigeria.

Idowu and Babatunde (2012) investigated the effect of financial reform on capital market development in Nigeria over the period 1986 to 2010. The study used ordinary Least square (OLS) techniques and Chow-break-point Test. The result revealed that the financial reform of 1995 impacted significantly on the capital market development in Nigeria. However, finding revealed that the variables that represent the development of the banking sector, the activities of the Central Bank and other financial institutions interacted negatively with market capitalization which implies that the activities of those institutions deterred the development of the capital market.

Angahar and lorpev (2012) empirically analyzed the effect of insecurity on capital market performance and economic growth in Nigeria. The study used data on peace index (PINDEX) and peace score (PSCORE) as proxy for insecurity, market capitalization as proxy for capital market performance and gross domestic product (GDP) a proxy for economic growth and total of listed equity and government stock as control variable collected from the global peace index (GPI), central bank of Nigeria (CBN) annual report, securities and exchange (SEC) annual report and Nigerian stock Exchange (NSE) annual report for a period of five years (2007-2011). Multiple regression analysis technique was employed while the result showed a negative relationship between capital market performance, economic growth, and insecurity in Nigeria. Particularly, the result showed that peace index is statically significant to capital market performance while peace score is not. However, peace score is statistically significant to economic growth while peace index is not statically significant. The study recommended that government at all level should not rest until peace is restored in the country so as to enable the capital market contribute positively to economic growth, at the same time help in the attainment of vision 2020.

Onulaka (2014) examined the impact of adoption of IFRS in Nigeria capital market; looking at the challenges facing the preparers and auditors of IFRS based financial statements in Nigeria. The study used structured questionnaire for primary data collection and analysis of variance (ANOVA) technique for the analysis. Findings revealed an increase in the volume of trading in the capital market and also the training gap on the part of preparers and auditors of IFRS based financial statement. 


\section{Method of Data Analysis}

\subsection{Sources of Data}

Secondary data was collected on each of the above stated variables, covering the period of 1990 to 2018 . The choice of this period is to make room for a broad coverage of the capital market indicators, as well as the investigation of both the short run and long run relationship between capital market development and economic growth in Nigeria. These annual data series were collected majorly from CBN Statistical Bulletin. CBN Annual Report and Statement of Accounts (various issues), NSE books, and SEC Market Bulletins.

\subsection{Data Analysis Technique}

In order to ensure variables used in this study are not spurious, the stationarity of variables was initially tested using the Augmented Dickey-Fuller (ADF) test. This was followed with a co integration test after the stationarity of variables have been established. The estimation technique used, drawn from developments in the co-integration theory, is the Error Correction Mechanism (ECM). Granger and Newbold (1974) and Engle \& Granger (1987) have proved that co-integration is a sufficient condition for an ECM formulation. The estimation was done with the aid of the E-views 8.0. version.

\subsection{Model Specification}

The study formulated four testable null hypotheses which states that all the independent variables under study (savings accumulation, gross fixed capital formation, labour force, and stock market capitalization) does not significantly affect gross domestic product. Multiple regression analysis was employed to test the stated hypotheses. The multiple regression model was specified as follows:

$\mathrm{RGDP}=\mathrm{f}(\mathrm{SAV}, \mathrm{GFCF}, \mathrm{LABF}, \mathrm{FCR})$

The econometric form of the model is as follows

$$
\mathrm{RGDP}_{\mathrm{t}}=\beta_{\mathrm{o}}+\beta_{1} \mathrm{SAV}_{\mathrm{t}}+\beta_{2} \mathrm{GFCF}_{\mathrm{t}}+\beta_{3} \mathrm{LABF}_{\mathrm{t}}+\beta_{4} \mathrm{FCR}_{\mathrm{t}}+\mu_{\mathrm{t}}
$$

Where:

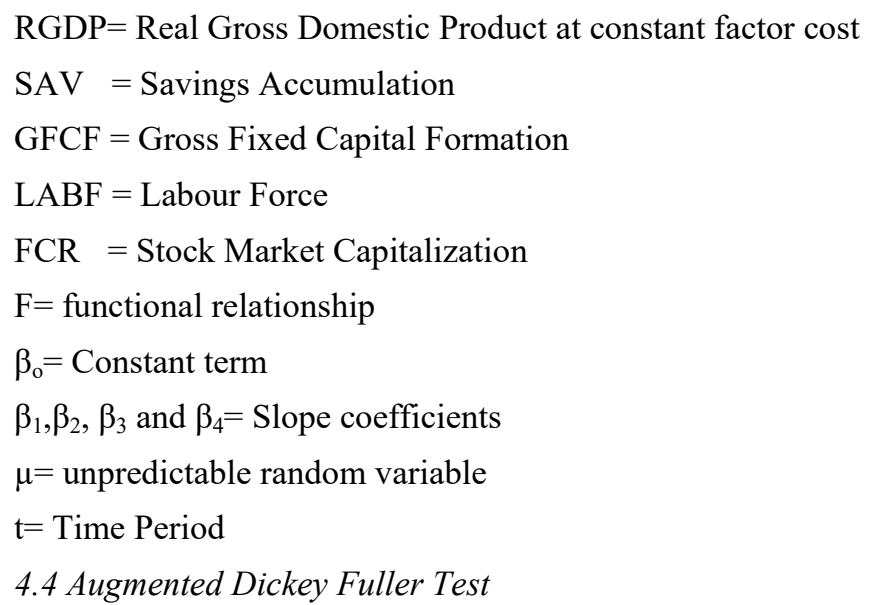

The ADF Test shall be used to test for the existence of unit root. In order not to run a spurious regression, it is worthwhile to carry this test to make sure that all the variables are mean reverting, that is, they have constant mean, constant variance and constant covariance. The model is given as:

$$
\Delta Y_{t}=\beta_{1} t+\delta Y_{t-1}+\sum_{i=1}^{m} \alpha_{i} \Delta Y_{t-i}+\varepsilon_{t}
$$

Decision Rule: If the ADF test statistic is greater than the MacKinnon critical value at 5\% (all in absolute term), the variable is said to be stationary. Otherwise it is non-stationary.

\subsection{Cointegration Test}

Econometrically speaking, two variables will be cointegrated if they have a long-term, or equilibrium relationship between them. Cointegration can be thought of as a pre-test to avoid spurious regressions situations (Granger, 1986). As recommended by Gujarati (2004), the ADF test statistic will be employed on the residual. The model is specified as follows: 


$$
\mu_{\mathrm{t}}=\beta_{\mathrm{o}}+\beta_{1} \mathrm{RGDP}_{\mathrm{t}}+\beta_{2} \mathrm{SAV}_{\mathrm{t}}+\beta_{3} \mathrm{GFCF}_{\mathrm{t}}+\beta_{4} \mathrm{LABF}_{\mathrm{t}}+\beta_{5} \mathrm{FCR}_{\mathrm{t}}
$$

Decision Rule: If the ADF test statistic is greater than the critical value at $5 \%$, then the variables are cointegrated (values are checked in absolute term).

\section{Decision rule}

If the augmented dickey fuller statistics is greater than the critical value at $5 \%$, then the variables are cointegrated but if the ADF test is less than the critical value at 5\% the variables are not cointegrated i.e. they don't have a long run relationship at equilibrium

\subsection{Error Correction Model (ECM)}

However, if there exist a long run relationship (cointegration) among the time series variables, the error correction model (ECM) will be estimated to derive the numerical values of the speed of short run adjustment to long run equilibrium.

The error correction model is specified as follows:

$$
\Delta \mathrm{RGDP}_{\mathrm{t}}=\propto_{0}+\propto_{1} \Delta \mathbf{S} \mathbf{A} \mathbf{V}_{\mathbf{t}}+\propto_{2} \Delta \mathbf{G F C F}_{\mathbf{t}}+\propto_{3} \Delta \mathbf{L} \mathbf{A} \mathbf{B} \mathbf{F}_{\mathbf{t}}+\propto_{4} \Delta \mathbf{F} \mathbf{C} \mathbf{R}_{\mathbf{t}}+\epsilon_{\mathrm{t}} \propto_{2} \mu_{\mathrm{t}-1}
$$

\section{Empirical Analysis and Results}

Table 1. Unit Root Test Results

\begin{tabular}{lccc}
\hline Variables & ADF test Stat & $5 \%$ critical value & Order of integration \\
\hline RGDP & -4.888542 & 0.0000 & $\mathrm{I}(1)$ \\
SAV & -2.392139 & 0.0188 & $\mathrm{I}(1)$ \\
GFCF & -8.000107 & 0.0000 & $\mathrm{I}(1)$ \\
LABF & -4.364511 & 0.0001 & $\mathrm{I}(1)$ \\
FCR & -5.797069 & 0.0000 & $\mathrm{I}(1)$ \\
\hline
\end{tabular}

Source: E-view output, computed by the Author and result of ADF stationarity tests.

Table 1 presents the results of ADF test for Unit root; it can be found that all the time series variables are stationary at first difference (RGDP, SAV, GFCF, LABF and FCR). Not having a stationarity time series data indicates not having a short run relationship among the individual time series data, this result is expected since most macro- economic time series variables are known to exhibit such behavior.

Table 2. Result of Johansson Co integration Test

\begin{tabular}{llllc}
\hline Variables & Test Statistic & Critical-Value 5\% & Order of integration & P-value of t-stat \\
\hline Residual & -5.593744 & -3.612199 & $\mathrm{I}(0)$ & 0.0007
\end{tabular}

Source: Authors computation from result of co integration test.

From the result of table 2, the ADF test statistics (-5.593744) is greater than the 5\% critical value(-3.612199) in absolute terms. This implies that the residuals are stationary (i.e. the variables are co-integrated or that the linear influence of the independent variables cancels out).. Therefore, there is a long run relationship between the variables.

Table 3. ECM Test Result

\begin{tabular}{ll}
\hline Variables & Coefficient \\
\hline ECT(-1) & -0.189558
\end{tabular}

Source: Authors computation from result of ECM test. 
FromTable 3, the magnitude of the short run disparity is -0.189558 , that is to say the degree of the short run dynamics is $19 \%$. This shows a low speed of adjustment to equilibrium after a shock.

Table 4. Multiple Regression Result

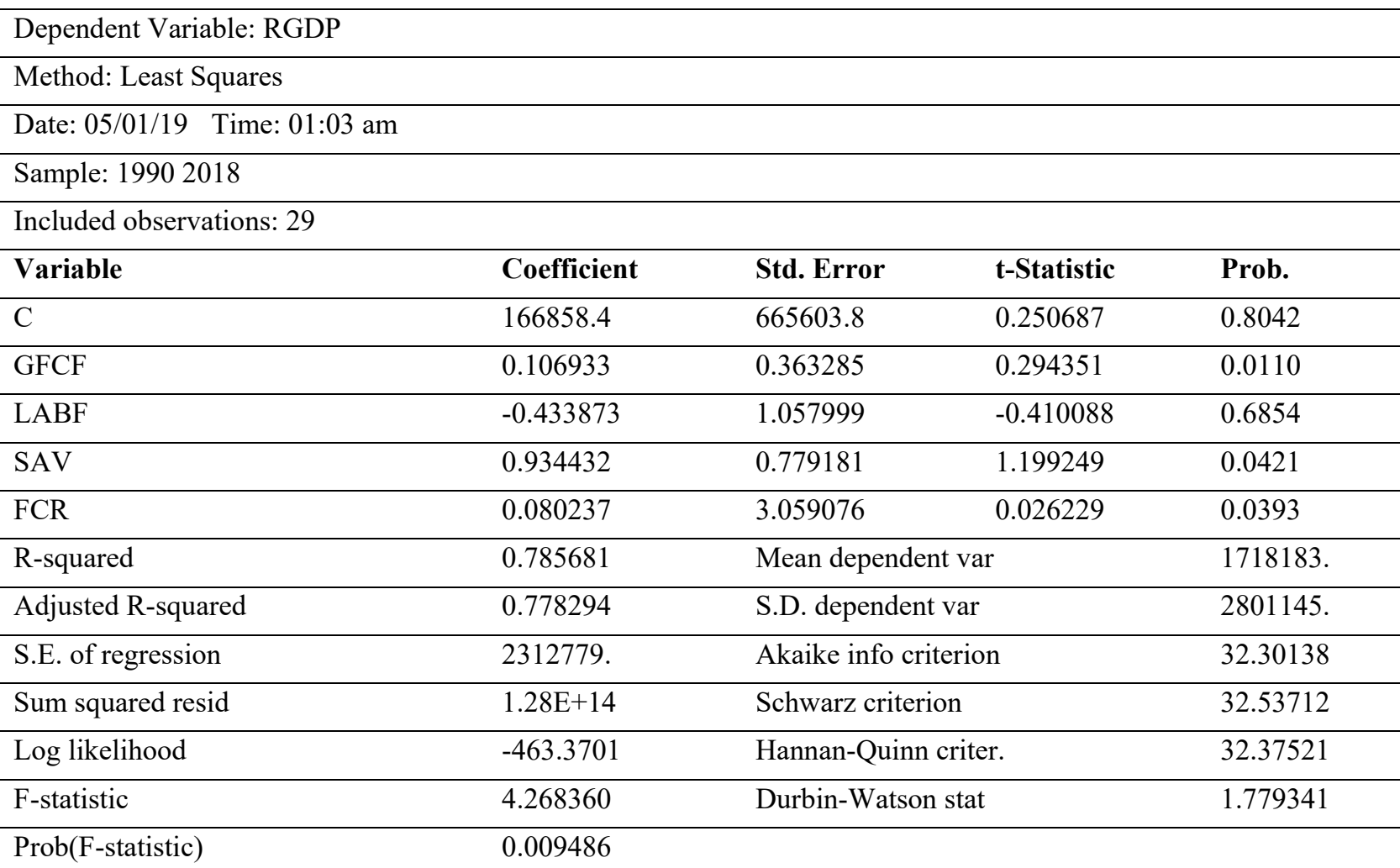

Source: E-view output, computed by the Authors.

The table 4 indicates that the probability value of t-statistics associated to Stock Market Capitalization (FCR) is given as 0.0393 , Savings accumulation (SAV) is given as 0.042 , gross fixed capital formation is given as 0.0110 while that of Labour force formation is 0.6854 . The implication is that all the variables are significant in explaining the economic growth in Nigeria except labour force which was found to be insignificant. The regression coefficient is obtained as 0.106933 for GFCF. This implies that if we hold every other variable affecting the Real Gross Domestic Product Constant that a unit increase in the gross fixed capital formation will lead to a corresponding increase in the real gross domestic product on the average. That of labour force is given as -0.433873 , this means that the decrease in the Labour force will lead to about -0.433873 decrease in the RGDP. More so, Stock market capitalisation has it that its coefficient is 0.080237 which depicts that a one-unit increase in the stock market capitalisation will lead to 0.080237 increase in the real gross domestic product on the average.

Also, the coefficient of determination (R-square) is obtained to be 0.785681 , this implies that the explanatory variables account for about $78.57 \%$ of changes in the dependent variable. The probability value of the f-stat is 0.009486 , suggesting that the variables have joint influence on the regression plane. More so, the Durbin Watson Stat is 1.779341 which is approximately 2 , implying no problem of autocorrelation in the estimated model.

\section{Discussion of Findings/Recommendations}

The study investigated empirically impact of capital market on economic growth in Nigeria from 1990 to 2018. To achieve this objective, an error correction model was estimated for economic growth. Findings from the study revealed that all the variables of interest are significant except labor force which is seen to be insignificant in explaining the economic growth in Nigeria. It follows therefore that:-

i. Gross fixed capital formation has a positive and significant effect on real gross domestic product in Nigeria.This implies that a unit increase in the gross fixed capital formation leads to a corresponding increase in the real gross domestic product when other variables are held constant. 
ii. Labour force has a negative and insignificant effect on real gross domestic product in Nigeria. It implies that a unit decrease in the labour force leads to the same decrease in the real gross domestic product.

iii. Savings accumulation has a positive and significant effect on real gross domestic product in Nigeria. It implies that the rate of Savings Accumulation is directly proportional to the value of real gross domestic product in Nigeria.

iv. Stock market capitalization has a positive and significant effect on real gross domestic product in Nigeria. The implication is that a unit increase in the stock market capitalization leads to increase in the real gross domestic product.

In the bid to enhance the development of the Nigerian capital market as the engine of economic growth, the study in keeping with the findings recommends as follows:

i. Government should remove impediments to stock market development in the form of tax, legal and regulatory barriers because they are sometimes disincentives to investment.

ii. In order to increase the ease with which investors can purchase and sell shares, thus guaranteeing liquidity on the stock market, the Nigerian Security and Exchange Commission should improve on the trading system. Given that the stock market operate in a macroeconomic environment, it is therefore necessary that the environment must be an enabling one that will promote and encourage investment opportunities for local and international investors.

iii. To significantly enhance labour force participation especially in capital market activities, more priority should be accorded to human capital development through more educational funding, scholarship programmes and educational grants. Other programmes such as vocational training and skill acquisition could also be built into the educational system to improve on the quality of labour force and professionals.

iv. The value of the total traded securities and equities revealed no direct relationship with economic growth indicator-gross domestic product growth rate. This suggests that companies listed on the Stock Exchange should be mandated to provide timely electronic information on their operations such as quarterly and annual financial statements, in order to enable the market learn, absorb and act on information quickly leading to market efficiency and precise pricing of securities. With the existence of a positive relationship between stock market development and economic growth, it is pertinent to recommend that there should be sustained effort to stimulate productivity in both the public and private sectors. The Nigerian government should employ appropriate trade policies that promote the inflow of international capital and foreign investment, so as to enhance the production capacity of the nation.

Capital Market regulators especially the Securities and Exchange Commission should be more open to innovations and be flexible without jeopardizing the interest and protection of investors as well as the efficiency of the market. The Commission needs to encourage more companies to list in the market so as to expand it and give investors better options for investment. Recent experience has shown that the confidence of many shareholders is waning due to the declining fortune of the stock market and many are reluctant to invest in shares and other securities.

\section{References}

Adelope I., Omoleso, K., \& Obalola, M. (2011). Impact of corporate governance on foreign direct investment in Nigerian. Retrieved from http/ssm.com/abstract $=1514982$

Akerlof, G. A. (1970). The market for lemons: quarterly uncertainty and the market mechanism. The Quarterly Journal of Economics, 84(3), 488-500. https://doi.org/10.2307/1879431

Alchian, A. A., \& Demsetz, H. (1972). Production, information costs and economic organisation. American Economic Review, 62, 772-795.

Al-Faki, M. (2006). The Nigerian Capital Market and Socio- economic Development. Paper Presented at a Distinguished Faculty of Social Science Public lecture, University of Berlin, 26, 9-16.

Alnodel, A. (2014) the effect of the adoption of international financial Reporting Standards on capital markets integration in the Gulf Cooperation council countries. Journals of International Accounting Research conferences. The Hong Kong Polytechnic University. 
Angahar, P. A. \& Lorpev, L. (2012). An analysis effects of security on capital market and economic growth of Nigeria. International Journal of Academic Research in Accounting finance and Management Sciences, 2(3), 207-216

Aremu, O.S., Suberu O. J., \& Ladip, O. O. (2011). Impact of the Nigerian capital market operations on the local investments in Nigeria. Journal of Research in International Business management, 1(8), 258-261

Azeez, S. O. (2009). Global Financial Meltdown: Nigerian Perspective. Nigeria accountant, 42(2), 6-7.

Bae, Tan, H., \& Welker, M. (2008). International GAAP differences. The impact of foreign analysts. The Accounting Review, 83(3), 593-628. https://doi.org/10.2308/accr.2008.83.3.593

Berry, A., \& Robertson, D. (2006). Overseas bankers in the Uk and their use of information for making lending decisions: changes from 1985. The British Accounting Review, 38(2), 175. https://doi.org/10.1016/j.bar.2005.10.004

Briggs, A. P. (2015). Capital market and economics growth of Nigeria. Research Journal of Finance and Accounting, 6(9), 82-93.

Bruggemann, U., HItz, J.-M., \& Sellhorn, T. (2013). Intended and unintended consequences of mandatory IFRS adoption: A review of extant evidence and suggestions for future research. European Accounting Review, 22(1), 1-37. https://doi.org/10.1080/09638180.2012.718487

Cai, F., \& Wong, H. (2010). The effect of IFRS adoption on global market integration. International Business \& Economics Research Journal (IBER), 9(10). https://doi.org/10.19030/iber.v9i10.636

Cascino, S., \& Gassen, J. (2011). Comparability Effects of Mandatory IFRS Adoption. Discussion paper. https://doi.org/10.2139/ssrn.1402206

Chen, H., Tang, Q., Jiang, Y., \& Lin, Z. (2010). The role of international financial reporting standards in accounting quality: Evidence from the European Union. Journal of International Financial Management \& Accounting, 21(3), 220-278. https://doi.org/10.1111/j.1467-646X.2010.01041.x

Cragg, W. (2002). Business ethics and stakeholder theory. Business Ethics Quarterly, 12(2), 113-142. https://doi.org/10.2307/3857807

Defond, M., Hu, X., Hung, M., \& Li, S. (2011). The impact of mandatory IFRS adoption on foreign mutual fund ownership: The role of comparability. Journal of Accounting and Economics, 51(3), 240-258. https://doi.org/10.1016/j.jacceco.2011.02.001

Donwa, P. \& Odia, J. (2010). An empirical analysis of the impact of the Nigeria capital market on her socio-economic development. Journal of Social Studies, 24(2), 135-142. https://doi.org/10.1080/09718923.2010.11892845

Donwa, P., \& Odia, J. (2011). Effect of the consolidation of the banking industry on the Nigerian capital market. Journal of Economic, 2(1), 57-65. https://doi.org/10.1080/09765239.2011.11884937

Drake M. S., Myers, L. A., \& Yoa, L. (2010). Are Liquidity Improvement Around the Mandatory Adoption of IFRS Attributable to Comparability Effect or to Quality Effects? AAA. https://doi.org/10.2139/ssrn.1466353

Efobi, U.R., \& Bwala, A. (2013). Voluntary information disclosure practiced of listed companies in Nigeria. ICAN Journal of Accounting \& Research, 2(1), 13-30.

Eguakun C. O. (2005). The Nigerian capital market: Impact on economic growth (Master's thesis, unpublished. Benuin City. University of Benin, 1-56).

Ewah, S., Esang, A., \& Bassey, J. (2009). Appraisal of Capital Market Efficiency on Economic Growth in Nigeria. International Journal of Business and Management, 4(12), 219. https://doi.org/10.5539/ijbm.v4n12p219

Francis, J. R., Huange, S. X., \& Khurana, I. K. (2015). The role of similar accounting standards in cross-border mergers and acquisitions. Contemporary accounting research. https://doi.org/10.1111/1911-3846.12176

Freeman, R. (1984). Strategic Management: A Stakeholder Approach. Boston: Pitman.

Gambari, Y. (2010). Issues in the Implementation of IFRS. Accounting and Financial Reporting Issue4s; Toronto; CICA.

Gaumnitz, J. E., \& Daugall, A. E. (1980). Capital Markets and institutions (4th ed.). Englewood Cliffs; Pre. 
Guggiola, G. (2010). IFRS adoption in the EU, accounting harmonization and markets efficiency: A reviewi. The International Business \& Economics Research Journal, 9(12), 99. https://doi.org/10.19030/iber.v9i12.350

Idowu, A.\& Babatunde, M. A. (2012). Effect of financial reforms on capital market development in Nigeria. Asian Journal of BUSINESS AND Management Sciences, 1(8), 4452.

Jensen, M. C., \& Meckling, H. W. (1976). THEORY OF THE FIRM: Managerial behavior, agency costs and $\begin{array}{lllll}\text { ownership structure. Journal of Financial Economics, 305-360. } & \text { 3, }\end{array}$ https://doi.org/10.1016/0304-405X(76)90026-X

Kimeli, E. K. (2017). IFRS adoption and capital markets. Journal of finance and Accounting, 5(1), 19-30.

Li, F., \& Shorff, N. (2010). Financial reporting quality and economic growth. https://doi.org/10.2139/ssrn.1265331

Mardini, G. H. (2012). The impact of IFRS 8 on segmental reporting by Jodankian listed companies an analysis of disclosure practices and some stakeholder's perceptions. Unsullied $\mathrm{PhD}$ thesis, University of Dundee. https://doi.org/10.1108/20421161211196139

Munter, P., Reckers M.J. (2009). IFRS and collegiate accounting curricula in the United States: 2008. A survey of the current state of education conducted by KPMG and the education committee of the American ACCOUNTING Association. Issues in Accounting Education. 24(2), 131-139. https://doi.org/10.2308/iace.2009.24.2.131

Odife, D., (200). THE Evolution of the Nigerian Capital Market and the Present Reform. Abuja Conference on Legislating for the Capital Market Abuja, 1-5.

Okala, K. E (2012). Adoption of IFRS and financial statement effects: The perceived implications on FDI and Nigeria economy. Australian Journal of Business and Management Research, 2(5), 76-83.

Olisaemeha. A G (2009). The meltdown of Nigerian capital market: cause and consequences. Retrieved from www.nairaland.com/24108/meltedowm-nigerian-capital-market.

Oluwatosin, E. O., Adekanye, T., \& Yusuf, S. A. (2013). Empirical analysis of the impact of capital market efficiency on economic growths and development in Nigeria. International Journal of Accounting and Financial Reporting, 4(2), 294-311.

Onulaka P. N. (2014). Impact of Adoption of IFRS in Nigeria Capital Market, Preparers of Financial Statement and Auditors. International Journal of Sciences and Research (IJSR), 3(11) 149-158.

Osaze, E. B. (2007). Capital Markets Africa \& Global. Lagos: Book house Company.

Sanusi, L. S. (2010). Global Financial meltdown and the Reform in the Nigeria Banking Sector. Public lecture Delivered at the Convocation square, Abubaka Tafawa Balewa University, Bauchi.

Sanusi, L. (2009). Recent Development in Nigeria's Banking. Central Bank of Nigeria (CBN) (2009). Reporting for the second Quarter of 2009" Research Department Abuja Nigeria.

Soludo, C. (2008). Nigeria's Financial System Strategy 2010 plan. Proceeding of the Financial System Strategy 2020 International Conference. June 18,Abuja Nigeria.

Sule, O., \& Momoh, J. (2009). Capital market and the Nigeria industrial growth, financial growth financial system and economic growth. ACBN publication, 8-10.

Ukpia, N. A. (2002). The snag international accounting transactions. Journal of Accounting, 3(6), 214-22.

Watts, R., \& Zimmerman, J (1978). Toward a position theory of the determination of accounting standards. The Accounting Review, 53, 11-134.

Yip, R. W., \& Young, D. (2012). Does mandatory IFRS adoption improve information comparability? The accounting Review, 87(5), 1767-1789. https://doi.org/10.2308/accr-50192 